\title{
Childhood diet in relation to Sámi and Norwegian ethnicity in northern and mid-Norway - the SAMINOR study
}

\author{
M Brustad ${ }^{1, *}, C L$ Parr $^{2}, M$ Melhus ${ }^{1}$ and $E$ Lund $^{1}$ \\ ${ }^{1}$ Centre for Sámi Health Research, Institute of Community Medicine, University of Tromsø, N-9037 Tromsø, \\ Norway: ${ }^{2}$ Institute of Basic Medical Sciences, Department of Biostatistics, University of Oslo, Oslo, Norway
}

Submitted 6 December 2006: Accepted 27 March 2007: First published online 5 July 2007

\begin{abstract}
Objective: The purpose of this work was to identify dietary patterns in the past using cluster analysis of reported diet in childhood, and to assess predictors for dietary patterns in relation to ethnicity in the population in the Sámi core areas in Norway. The Sámis are an indigenous population living in the border areas of Norway, Sweden, Finland and Russia.

Design: Population-based, cross-sectional study, using self-administered questionnaires. A food-frequency questionnaire covering selected food items eaten in childhood was used. The questionnaire also provided data on ethnicity.

Subjects and setting: This study was based on data collected from 7614 subjects participating in The Population Based Study of Health and Living Conditions in Areas with a Mixed Sámi and Norwegian Population (the SAMINOR study) who grew up in the SAMINOR geographical areas, i.e. areas with mixed Sámi and Norwegian populations in Norway.

Results: Four dietary clusters were identified: a reindeer meat cluster; a cluster with high intakes of fish, traditional fish products and mutton, in addition to food sources from the local environment; a Westernised food cluster with high intakes of meat balls and sausages; and a cluster with a high intake of fish, but not any other foods in the questionnaire. The cluster distribution differed by ethnicity, but the effect of ethnicity on diet differed by coastal and inland residence.

Conclusion: Our study has shown that data gathered through the limited questionnaire could be used to group the study sample into different dietary clusters, which we believe will be useful for further research on relationships between diet in childhood and health in the Sámi core areas in Norway.
\end{abstract}

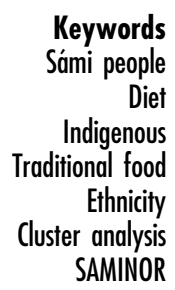

The Sámi people are an indigenous population constituting an ethnic minority in Norway. Only a few recent studies have investigated diet in the population living in the Sámi core areas in Norway and these studies are based on rather small sample sizes ${ }^{1-4}$. Dietary assessment studies among indigenous peoples, mainly from Arctic North America, have shown that indigenous traditional food with its high nutrient density constitutes an important source of essential nutrients, in addition to having social and cultural benefits ${ }^{5}$. For Inuit women living in Nunavik, northern Quebec, Canada, Blanchet et al. ${ }^{6}$ found that although market food contributed most to the women's energy intake, $40 \%$ of the intake of several nutrients including protein, vitamin $\mathrm{D}$, phosphorus and zinc was derived from traditional food. Furthermore, low intakes of some nutrients have been observed to accompany a reduction in the consumption of a traditional diet. In particular, the intake of vitamin $\mathrm{D}$, which is found in high concentrations in a limited number of foods, has been negatively associated with dietary change towards a more 'modern' dietary pattern among Arctic populations ${ }^{7,8}$. Therefore, rapid dietary change towards decreased use of traditional foods and its impact on health are of special concern ${ }^{7,9}$.

No former comprehensive nutritional epidemiological study has been carried out in the Sámi areas of Norway on diet in relation to ethnicity. Significantly lower incidence rates of cancer in colon, breast, lung and prostate have been found in the Sámi people in Norway compared with the regional reference population ${ }^{10}$. Both genetic ${ }^{11}$ and lifestyle factors including diet and physical activity ${ }^{10}$ have been proposed as possible explanations for the observed differences.

Diet in childhood has been proposed to affect adult risk of some health outcomes and may be an important parameter among several lifestyle factors that serve as predictors for cancer risk ${ }^{12}$. However, little is known about the dietary intake in childhood of adult and elderly 
Sámi living today. Most of our knowledge about the diet of Norwegian Sámi in the past is limited to ethnographic and historical descriptions of food use. In the 1960s a number of quantitative assessments of diet were undertaken in communities with a concentrated Sámi population, but the studies were small and ethnicity not always recorded $^{13-15}$. Thus, the development of methods for assessing childhood diet are needed and can be of great value in further research on predictors for cancer risk in the Sámi population.

The purpose of the present work was to identify dietary patterns in the past using cluster analysis of reported diet in childhood in the population living in the Sámi core areas in Norway. We also investigated predictors of dietary patterns, including ethnicity, geographical residence in childhood (coast or inland), age, gender and boarding school attendance, and whether the diet has been subject to dietary change.

\section{Method}

\section{The SAMINOR study}

This paper is based on data from The Population Based Study of Health and Living Conditions in Areas with a Mixed Sámi and Norwegian Population (the SAMINOR study), which has been described in detail elsewhere ${ }^{16}$. The overall aim of the SAMINOR project has been to study health and diseases in relation to living conditions among the Sámi population and compare them with the Norwegian population in the same area. The SAMINOR study was conducted by the Centre for Sámi Health Research, Institute of Community Medicine at the University of Troms $\varnothing$. The administration and data collection for the study were carried out in collaboration with the National Health Screening Programme, now incorporated in the Norwegian Institute of Public Health. The data collection for the SAMINOR study was carried out in 2003 and 2004. Biological samples (blood samples), physical measures (blood pressure, pulse recording) and anthropometric measurements were gathered in addition to questionnaire data on social conditions, ethnicity, self-reported physical and mental health, and diet in childhood and today. The questionnaires were selfadministered and machine-readable.

\section{Geograpbical area}

The SAMINOR study was conducted in geographical areas of Norway with a mixed Sámi/Norwegian population. The study intended to cover all municipalities in Norway where more than $5-10 \%$ of the population reported themselves as Sámi in the 1970 census ${ }^{17}$, based on the definition of Sámi as a person with at least one grandparent with Sámi as the spoken home language. In addition, some selected districts were included from

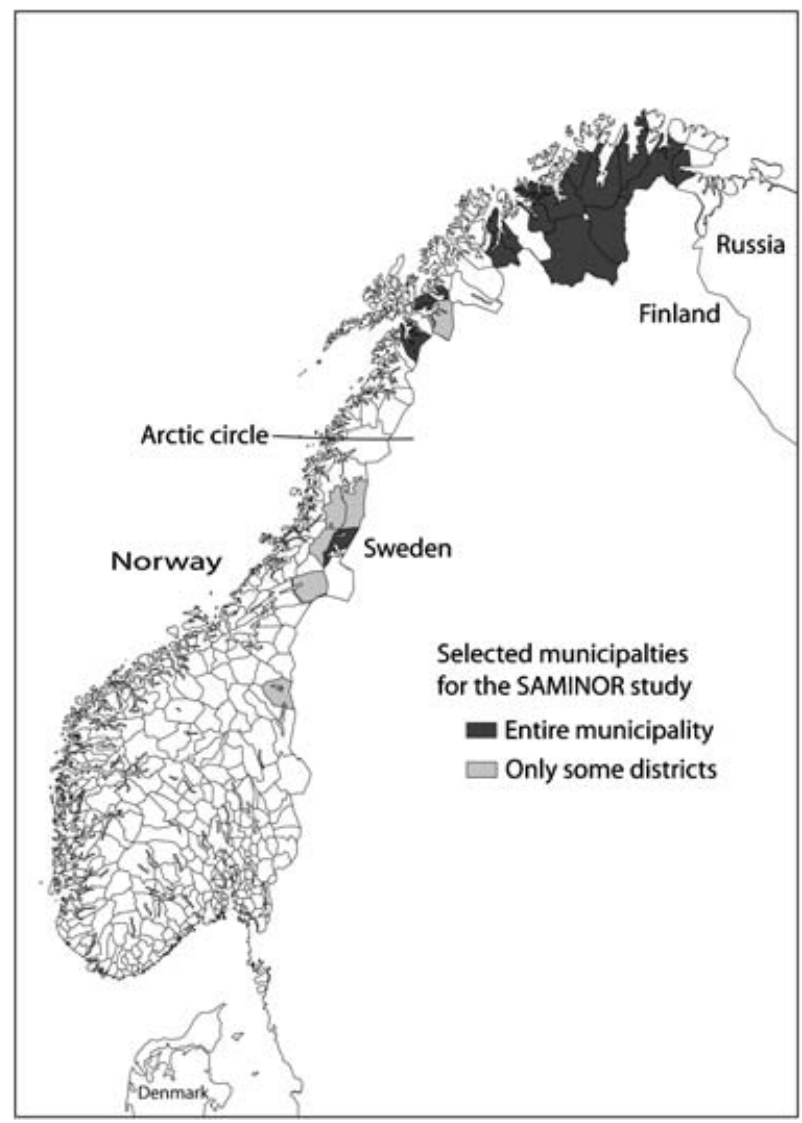

Fig. 1 Municipalities investigated in the SAMINOR study. Finnmark county: Karasjok, Kautokeino, Porsanger, Tana, Nesseby, Lebesby, Alta, Loppa, Kvalsund. Troms county: Kåfjord, Kvænangen, Storfjord, Lyngen, Skånland og Lavangen. Nordland county: Tysfjord, Evenes and parts of Hattfjelldal, Grane and Narvik. Nord Trøndelag county: Røyrvik and parts of Namskogan and Snåsa. Sør Trøndelag county: part of Røros

municipalities with an overall lower proportion of subjects with Sámi ethnicity. Altogether, 24 municipalities, often referred to as the core area for Sámi settlement, stretching from mid-Norway to the Russian border in northern Norway were included in the survey. Figure 1 shows the geographical areas referred to as the SAMINOR area in the text.

\section{Sample}

Everyone in the defined SAMINOR area (Fig. 1) aged 36-79 years was initially invited to participate in the SAMINOR study, some 27151 subjects in total. The initial questionnaire was completed by 16404 individuals with a response proportion of $60.4 \%$. Questions on diet and residence during childhood were asked in an additional questionnaire having 13419 respondents (49.4\%). Among these respondents, 174 subjects had missing on the questions on diet in childhood, thus leaving 13245 (48.8\%) subjects with data on childhood diet. Our analyses were further restricted to the 7631 subjects who 
lived in the SAMINOR area in their childhood (7-14 years), based on self-reported residence. Subjects with missing data on ethnicity $(n=16)$ or immigrants $(n=1)$ were excluded from the analysis. Thus, the final sample size of the present study was 7614 .

\section{Etbnicity}

In Norway, no systematic registration of ethnicity is available for research purposes, except for the last census in $1970^{17}$. To capture ethnicity (Norwegian, Sámi, Kven or 'other'), the SAMINOR study included questions on the language used at home by the grandparents, parents and the subject, in addition to the ethnic background of the parents and the subjects, and also a question on selfperceived ethnicity. Based on these questions, ethnicity was divided into four groups: one Norwegian and three groups for Sámi affiliation. In the analysis the Kvens, a population group of Finnish origin $(n=684)$, was merged with the Norwegian group because they did not differ with respect to diet in childhood. Persons with both Kven and Sámi affiliation were considered Sámi. For the Sámi ethnic affiliation the three groups used in the analyses were defined as follows: Sámi I - three generations with Sámi language, all grandparents, both parents and the participant used Sámi as home language; Sámi II - at least two Sámi-speaking grandparents; Sámi III - some Sámi affiliation, i.e. at least one Sámi mark, like language, selfperceived ethnicity or family background.

\section{Food frequency data}

The food-frequency questionnaire data presented here were based on a section of questions regarding diet in childhood and boarding school attendance. Participants were instructed to think about the food eaten at home before moving out or the food at boarding school for those who spent most of the school year there. Questions were asked about the consumption frequency of 11 selected food items believed to be part of a traditional diet in the study areas based on historical description of $\operatorname{diet}^{15,18-20}$ : 'boiled/fried fish', 'reindeer meat', 'blood products', 'mutton', 'meat balls, sausages', 'fish products', 'fish liver and roe', 'porridge, pancakes', 'wild berries', and the wild plants 'mountain sorrel' (Oxyria digyna) and 'angelica' (Angelica archangelica). For 'boiled/fried fish' and 'reindeer meat', the response options were 'never', '1-11 per year', ' 1 per month', '2-3 per month', '1-2 per week', '3-4 per week' and ' $\geq 5$ per week'. The two highest response categories were included to try to identify those who were brought up on a traditional diet, which was high in fish on the coast and in reindeer meat in inland areas (mainly among the reindeer-herding Sámi). Wild berries and plants had the response options of 'never', ' $1-5$ per year', '6-11 per year', ' 1 per month', '2-3 per month', ' $1-2$ per week' and ' $\geq 3$ per week'. In the design of the questionnaire, it was difficult to estimate reasonable consumption frequencies as wild foods are seasonal and may be eaten irregularly. The remaining foods had the response options of 'never', ' $1-11$ per year', ' 1 per month', '2-3 per month', '1 per week', '2 per week' and ' $\geq 3$ per week'. Participants were also asked about their intake of cod-liver oil supplements (yes/no) and fresh cod-liver oil served with food. The final question was 'Is the food you eat now different from what you got during childhood?', with response options of 'no', 'slightly different', 'quite different' and 'very different'.

\section{Statistical analysis}

SAS statistical software, version 9.1 (SAS Institute), was used for statistical analysis. In our analyses the municipalities were divided into two regions: coast and inland. The food frequencies were converted to times per week and analysed using cluster analysis. The plant 'angelica' was the only food not included due to a low response rate and the fact that $90 \%$ reported never to have eaten it.

The principle of cluster analysis is to divide the subjects into groups (clusters) in such a way that subjects within a cluster are more similar than subjects in different clusters. Instead of analysing different foods separately, cluster analysis gives us the possibility of viewing the whole vector of food items simultaneously. We used a two-step approach to clustering by first using $k$-means clustering with Euclidian distance (SAS PROC FASTCLUS) ${ }^{21}$, making 50 initial clusters which were used as input to Ward's minimum variance clustering (SAS PROC CLUSTER). This two-step procedure is recommended by SAS when clustering on large datasets.

Differences in food frequencies (times per week) by cluster were tested using analysis of variance followed by the Tukey-Kramer test for pairwise comparisons of clusters. Pearson's $\chi^{2}$ test was used when testing for differences in dietary pattern among different ethnic groups and when testing degree of change in diet by different characteristics. All tests were two-sided with a significance level of 0.05 .

\section{Etbics}

The study was approved by the Regional Ethical Committee for Medical Research in North-Norway. The National Data Inspectorate (Datatilsynet) gave approval for storing of individual information and for later linkages.

\section{Results}

\section{Characteristics}

Selected characteristics of the study sample are presented in Table 1. The mean age of the participants was 54.4 (standard deviation 11.0 ) years. Nearly $40 \%$ of the study 
sample reported Sámi affiliation: being the third generation using Sámi language (Sámi I) (13.4\%), having at least two Sámi-speaking grandparents (Sámi II) (18.1\%) or other Sámi affiliation (Sámi III) (8.2\%).

\section{Dietary clusters}

Four clusters of dietary pattern were identified. The consumption frequency of different foods by cluster is

Table 1 Characteristics of study sample $(n=7614)^{*}$

\begin{tabular}{|c|c|c|}
\hline Characteristic & $n$ & $\%$ \\
\hline \multicolumn{3}{|l|}{ Age (years) } \\
\hline $36-49$ & 2774 & 36.4 \\
\hline $50-64$ & 3252 & 42.7 \\
\hline $65-79$ & 1588 & 20.9 \\
\hline \multicolumn{3}{|l|}{ Gender } \\
\hline Men & 3808 & 50.0 \\
\hline Women & 3806 & 50.0 \\
\hline \multicolumn{3}{|l|}{ Ethnicity } \\
\hline $\begin{array}{l}\text { Sámi I (three generations using } \\
\text { Sámi language) }\end{array}$ & 1020 & 13.4 \\
\hline $\begin{array}{l}\text { Sámi II (at least two Sámi-speaking } \\
\text { grandparents) }\end{array}$ & 1381 & 18.1 \\
\hline $\begin{array}{l}\text { Sámi III (others reporting some } \\
\text { Sámi affiliation) }\end{array}$ & 623 & 8.2 \\
\hline Kven & 684 & 9.0 \\
\hline Other Norwegians & 3906 & 51.3 \\
\hline \multicolumn{3}{|l|}{$\begin{array}{l}\text { Geographical area of residence } \\
\text { at age } 7-14 \text { years }\end{array}$} \\
\hline Inland & 1291 & 17.0 \\
\hline Coast & 6323 & 83.0 \\
\hline \multicolumn{3}{|l|}{ County of residence at age $7-14$ years } \\
\hline Finnmark & 4558 & 59.9 \\
\hline Troms & 1886 & 24.8 \\
\hline Nordland and Trøndelag & 1156 & 15.2 \\
\hline Moved during the age period & 14 & 0.2 \\
\hline \multicolumn{3}{|l|}{ Attended boarding school in childhood } \\
\hline Yes & 1622 & 22.2 \\
\hline No & 5694 & 77.8 \\
\hline
\end{tabular}

${ }^{*} n$ may not total to 7614 for all variables due to missing values. given in Table 2 . Cluster 1 was characterised by high consumption of reindeer meat and blood products. Cluster 2 was characterised by high consumption of fish, traditional fish products and mutton, as well as wild berries and plants from the local environment. Cluster 3 was characterised by a more Westernised diet with increased use of meat balls and sausages compared with the other groups. Finally, cluster 4 had a high frequency of fish consumption, but not of the traditional fish products or the other foods included in the questionnaire.

\section{Dietary pattern by etbnicity}

Table 3 shows the cluster distribution by ethnicity. The dietary cluster distribution for the Sámi I group was the most atypical compared with the other ethnic groups $\left(P<0.001, \chi^{2}\right.$ test). The cluster distributions for the two other Sámi groups were similar $\left(P=0.47, \chi^{2}\right.$ test $)$. The dietary pattern characterised by cluster 1 (reindeer meat) was found more often (36.6\%) in the group with three generations using Sámi language (Sámi I) than in the other ethnicity groups, where cluster 1 contributed $\leq 5 \%$. For the Norwegian ethnicity group, the dietary pattern characterised by cluster 3 (Westernised diet) was predominant (48.5\%).

\section{Geography - coast vs. inland and etbnicity}

Significant differences in cluster distributions were found between inland and coastal residence $\left(P<0.001, \chi^{2}\right.$ test $)$ (Table 3 ). The fish clusters were associated with coastal residence, whereas the clusters for reindeer-meat consumption and Westernised diet were more common in the inland areas.

Table 2 Characteristics of identified clusters ${ }^{\star}(n=7614)$

\begin{tabular}{|c|c|c|c|c|}
\hline & $\begin{array}{c}\text { Cluster } 1 \\
\text { Reindeer meat }\end{array}$ & $\begin{array}{c}\text { Cluster } 2 \\
\text { Fish and mutton, traditional }\end{array}$ & $\begin{array}{c}\text { Cluster } 3 \\
\text { Westernised diet }\end{array}$ & $\begin{array}{c}\text { Cluster } 4 \\
\text { Fish, less traditional }\end{array}$ \\
\hline$n(\%)$ & $562(7.4)$ & $1683(22.1)$ & $3270(42.9)$ & $2099(27.6)$ \\
\hline \multicolumn{5}{|l|}{ Food (food consumption in frequency per week) } \\
\hline Boiled/fried fish & 2.42 & 3.83 & 1.25 & 3.64 \\
\hline Reindeer meat & 3.91 & 0.24 & $\overline{0.34}$ & 0.26 \\
\hline Blood products & 0.76 & $\overline{0.35}$ & 0.22 & $\overline{0.22}$ \\
\hline Mutton & 0.61 & 1.07 & $\overline{0.59}$ & $\overline{0.81}$ \\
\hline Meat balls/sausages & $\overline{0.65}$ & 0.63 & $\overline{0.75}$ & 0.65 \\
\hline Fish products & 1.27 & $\overline{2.01}$ & 1.24 & 1.67 \\
\hline Fish liver and roe & $\overline{0.51}$ & 1.08 & 0.37 & 0.47 \\
\hline Porridge/pancakes & 1.04 & 1.09 & 0.93 & 0.90 \\
\hline Wild berries & 1.30 & 2.60 & $\overline{1.05}$ & $\overline{0.74}$ \\
\hline Wild plants - 'mountain sorrel' (Oxyria digyna) & 0.22 & 0.30 & 0.11 & $\overline{0.12}$ \\
\hline \multicolumn{5}{|l|}{ Other variables } \\
\hline Cod-liver oil as supplement (\%) & 63.9 & 75.2 & 75.3 & 72.6 \\
\hline Cod-liver oil served with fish (\%) & 27.7 & 44.4 & 26.2 & 40.0 \\
\hline Age (years, mean) & 55.1 & 57.3 & $\overline{52.2}$ & 55.5 \\
\hline
\end{tabular}

* Bold numbers mark foods with the significant highest frequency of intake. Underlined numbers indicate clusters with the significant lowest frequency of intake, tested by analysis of variance. More than one figure in either bold or underlined for each food indicates that the two lowest or two highest estimates were not significantly different. Variables for cod-liver oil tested by the $\chi^{2}$ test. 
Table 3 Cluster distribution by different characteristics $(n=7614)$

\begin{tabular}{|c|c|c|c|c|c|}
\hline & $\begin{array}{l}\text { Cluster } 1 \\
\text { Reindeer } \\
\text { meat }\end{array}$ & $\begin{array}{c}\text { Cluster } 2 \\
\text { Fish and mutton, } \\
\text { traditional }\end{array}$ & $\begin{array}{c}\text { Cluster } 3 \\
\text { Westernised } \\
\text { diet }\end{array}$ & $\begin{array}{l}\text { Cluster } 4 \\
\text { Fish, less } \\
\text { traditional }\end{array}$ & $P$-value* \\
\hline \multicolumn{6}{|l|}{ Cluster distribution (\%) among ethnic groups } \\
\hline Sámi I (three generations using Sámi language) & 36.6 & 13.6 & 34.0 & 15.8 & \\
\hline Sámi II (at least two Sámi-speaking grandparents) & 5.3 & 28.5 & 34.2 & 32.0 & \\
\hline Sámi III (others reporting some Sámi affiliation) & 3.9 & 27.6 & 36.1 & 32.4 & \\
\hline Other Norwegians & 2.0 & 21.3 & 48.5 & 28.2 & $<0.001$ \\
\hline \multicolumn{6}{|l|}{$\begin{array}{l}\text { Cluster distribution (\%) by geographical area of } \\
\text { residence at age } 7-14 \text { years }\end{array}$} \\
\hline Coast & 3.0 & 25.8 & 39.2 & 32.0 & \\
\hline Inland & 28.7 & 3.8 & 61.4 & 6.1 & $<0.001$ \\
\hline \multicolumn{6}{|l|}{ Cluster distribution (\%) by gender } \\
\hline Men & 6.5 & 18.7 & 47.7 & 27.1 & \\
\hline Women & 8.2 & 25.5 & 38.2 & 28.0 & $<0.001$ \\
\hline \multicolumn{6}{|l|}{ Cluster distribution (\%) by age groups (years) } \\
\hline $36-49$ & 7.6 & 14.2 & 53.9 & 24.3 & \\
\hline $50-64$ & 6.4 & 26.2 & 39.0 & 28.4 & \\
\hline $65-79$ & 9.0 & 27.5 & 31.9 & 31.6 & $<0.001$ \\
\hline \multicolumn{6}{|l|}{$\begin{array}{l}\text { Cluster distribution (\%) according to boarding } \\
\text { school attendance }\end{array}$} \\
\hline Attended boarding school & 17.5 & 23.5 & 33.9 & 25.2 & \\
\hline Did not attend boarding school & 4.4 & 21.5 & 45.7 & 28.4 & $<0.001$ \\
\hline
\end{tabular}

(a) $\square$ Cluster $1 \square$ Cluster 2 - Cluster $3 \square$ Cluster 4
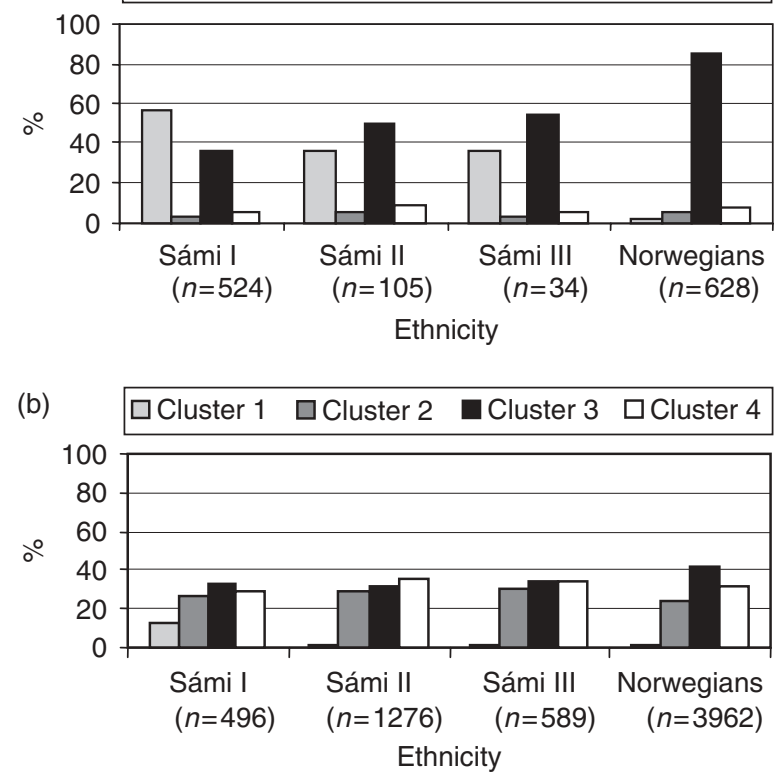

Fig. 2 Dietary cluster distribution by ethnicity: (a) subjects who grew up in the inland areas and (b) subjects who grew up in the coastal areas. Cluster labels: 1 - reindeer meat; 2 - fish and mutton, traditional; 3 - Westernised diet; 4 - fish, less traditional

Figures $2 \mathrm{a}$ and $2 \mathrm{~b}$ present the cluster distributions by ethnicity stratified on coast and inland residence. Overall, the cluster distributions were less affected by ethnicity in the coastal than the inland area. The distribution of clusters across the ethnic groups was more homogeneous in the coastal compared with the inland area. The cluster distribution patterns for Sámi II and Sámi III were similar within both inland and coastal strata $(P=0.82$ and 0.59 , respectively, $\chi^{2}$ test). For the inland stratum we could not statistically distinguish between Sámi I and Sámi III ( $P=0.10, \chi^{2}$ test). The cluster distributions for the other ethnic groups were significantly different from each other within each geographic stratum. Figures $2 \mathrm{a}$ and $2 \mathrm{~b}$ show that the proportion with a Westernised diet (cluster 3) increased with decreasing Sámi affiliation, whereas the opposite was seen for the reindeer-meat consumers (cluster 1). This trend was stronger in the inland stratum compared with the coast.

\section{Distribution of dietary patters by selected characteristics}

Significant differences in the distribution of dietary clusters were found for gender $(P<0.001)$ (Table 3$)$. Nearly half of the men were classified in cluster 3 (Westernised diet) compared with $38 \%$ of the women. More women than men (25.5\% vs. $18.7 \%)$ were in cluster 2 (high consumption of fish and traditional diet). The dietary cluster distribution differed by age group $\left(P<0.001, \chi^{2}\right.$ test $)$. No age effect was found for the reindeer-meat consumers, whereas for the two fish clusters (clusters 2 and 4) the proportion increased with age. The opposite was found for the Westernised dietary cluster (cluster 3). Cluster 2 had the highest mean age. The dietary clusters were similarly distributed between those who did and did not attend boarding school, except for the reindeer meat cluster, which was four times more common among those who reported to attend boarding school. 


\section{Dietary changes}

The highest proportion of subjects who answered that their diet today was not different from their childhood diet was found in dietary cluster 1 (reindeer meat) $(13.3 \%$ vs. $5.9 \%, 9.1 \%$ and $6.1 \%$ for cluster 2,3 and 4 , respectively) (Table 4). However, the highest proportion of subjects reporting that their diet has changed very much as adults was also highest in cluster 1 (13.4\%). In cluster 3 (Westernised), we found the lowest proportion of subjects who reported very different food habits today than in their childhood (4.3\%). The distribution of the degree of dietary change was not significantly different for the two fish clusters (clusters 2 and 4) $\left(P=0.56, \chi^{2}\right.$ test). Cluster 1 (reindeer meat) and cluster 3 (Westernised) were different from the other two clusters with respect to dietary change $\left(P=0.001, \chi^{2}\right.$ test). Table 4 shows that the proportion who reported a very different diet today compared with their childhood diet was more than doubled in the Sámi I group (12.1\%) compared with the proportion in the Norwegian ethnic group (5.5\%). For dietary change, no gender difference was found, but there were statistically significantly differences between geographical areas, age groups and for boarding school attendance (Table 4). Very different diet today compared with diet in childhood was positively associated with high age group and boarding school attendance. No change in diet was proportionally slightly more often reported among subjects from the coast compared with inland. However, the degree of change in diet was also assessed by geography within each dietary cluster, but no significant coast/inland effect was found (data not shown).

\section{Discussion}

The main finding in this study was that clusters of dietary patterns, based on reported consumption frequencies of selected food items used in childhood, differed by ethnicity. However, ethnicity was associated with geographic region defined as inland and coast, and may in part explain this result.

The effect of diet on many diseases, e.g. cancer, is hypothesised to occur long before the actual disease onset. Thus, measures of dietary intake in childhood could be useful in epidemiological studies. However, retrospective assessments of diet may have limited validity. Methodological issues regarding recall of remote diet have been discussed in detail elsewhere ${ }^{22}$. Most studies validating recall of past diet have looked at diet in earlier adulthood and few studies have validated recall of diet in childhood ${ }^{23}$. Dwyer et al. ${ }^{24}$ used data from the Harvard Longitudinal Study of Child Health and Development and found that for participants with median age 50 years, the median correlation for individual food items, between actual and recalled intakes, was 0.24 for age 30 years, 0.12 for age 18 years and 0.12 for ages 5-7 years. In the Nurses' Health Study, the reproducibility and validity of adult recall of adolescent diet gave correlations of $r=0.65$ (range, 0.50-0.77) and $r=0.40$ (range, 0.13-0.59), respectively, when assessing nutrient intakes based on mothers' recalled intakes as reference ${ }^{25}$. The values for food intake were 0.60 and 0.30 , respectively.

Although limited in number, some historical descriptions of diet from these areas are available and they

Table 4 Change in food habits by different characteristics $(n=7567)$

\begin{tabular}{|c|c|c|c|c|c|}
\hline & \multicolumn{4}{|c|}{$\begin{array}{l}\text { Is the food you eat today different from what } \\
\text { you ate during your childhood? }\end{array}$} & \multirow[b]{2}{*}{$P$-value ${ }^{\star}$} \\
\hline & No & Slightly different & Quite different & Very different & \\
\hline \multicolumn{6}{|l|}{ Cluster } \\
\hline 1 (Reindeer meat) & 13.3 & 48.8 & 24.6 & 13.4 & \\
\hline 2 (Fish and mutton, traditional) & 5.9 & 52.6 & 33.2 & 8.3 & \\
\hline 3 (Westernised diet) & 9.1 & 58.2 & 28.3 & 4.3 & \\
\hline 4 (Fish, less traditional) & 6.1 & 53.8 & 32.9 & 7.1 & $<0.001$ \\
\hline \multicolumn{6}{|l|}{ Ethnicity } \\
\hline Sámi I (three generations using Sámi language) & 9.2 & 47.9 & 30.8 & 12.1 & \\
\hline Sámi II (at least two Sámi-speaking grandparents) & 5.2 & 51.5 & 35.6 & 7.7 & \\
\hline Sámi III (others reporting some Sámi affiliation) & 6.7 & 52.0 & 34.2 & 7.2 & \\
\hline Other Norwegians & 8.6 & 58.1 & 28.2 & 5.1 & $<0.001$ \\
\hline \multicolumn{6}{|l|}{ Gender } \\
\hline Men & 8.2 & 54.7 & 30.9 & 6.3 & \\
\hline Women & 7.6 & 55.5 & 29.9 & 7.1 & 0.3 \\
\hline \multicolumn{6}{|l|}{ Age (years) } \\
\hline $36-49$ & 7.1 & 58.3 & 30.2 & 4.4 & \\
\hline $50-64$ & 7.4 & 56.2 & 30.1 & 6.3 & \\
\hline $65-79$ & 10.3 & 46.9 & 31.5 & 11.3 & $<0.001$ \\
\hline \multicolumn{6}{|l|}{ Geographical area of residence at age $7-14$ years } \\
\hline Coast & 7.3 & 55.4 & 30.8 & 6.5 & \\
\hline Inland & 10.6 & 53.2 & 28.5 & 7.6 & $<0.001$ \\
\hline \multicolumn{6}{|l|}{ Boarding school } \\
\hline Attended boarding school & 7.7 & 48.7 & 32.5 & 11.1 & \\
\hline Did not attend boarding school & 7.9 & 57.1 & 29.5 & 5.5 & $<0.001$ \\
\hline
\end{tabular}

${ }^{*} \chi^{2}$ test. 
support the validity of our findings. The work by Kloster ${ }^{18}$ based on dietary assessment from 1928/29 in coastal communities in Finnmark (the northernmost county in Norway) found a high intake of fish and fish products, in particular fish liver and fish-liver oil. Kloster also found ethnic differences and reported that the Sámi diet contained more fish and vitamin D than the diet of both Kvens and Norwegians. This observation supports our findings that the traditional fish cluster (cluster 2) was more dominant among the three Sámi ethnic groups than the Norwegian group. Dietary assessment studies from boarding schools in the inland in Finnmark conducted in the $1960 \mathrm{~s}^{15}$ describe frequent use of reindeer meat. This gives credibility to our finding that the reindeer meat cluster (cluster 1) was more prominent among those attending boarding school compared with those who did not. It is also important to add that the children at the boarding schools were mainly from reindeer-herding families. Moreover, from their dietary assessment in communities in inland Finnmark from the 1960s, Solvang and $\varnothing_{\text {grim }}{ }^{14}$ reported that the consumption of reindeer meat and blood was strikingly high among the reindeer herders, i.e. the Sámi.

A change towards a more Westernised dietary pattern with time could explain the finding that a Western diet (cluster 3) was more common among the youngest participants, whereas the fish clusters (clusters 2 and 4) were more common in the older age groups. Cluster 2 had the highest intake of mutton, which is in agreement with former ethnographical descriptions of combined fishing and sheep farming in the coastal population ${ }^{19,26}$.

Cluster 1 (frequent use of reindeer meat) seemed to be both the most stable and the most exposed to change. It could be that the shift away from traditional reindeer herding reduces access to traditional food and induces change towards a more Westernised dietary pattern, whereas those remaining in the reindeer herding profession are more able to keep their traditional food habits over time.

Despite methodological challenges, the dietary patterns and predictors identified in our study are in agreement with what has been reported in other studies conducted in this area, supporting the validity of our findings. Thus, we believe that our work indicates interesting predictors of childhood diet and that the results, when treated with caution, can be useful in further research. In light of new research suggesting different cancer risks between fish- and meat-eaters ${ }^{27}$, our defined dietary clusters (a group with high meat consumption and a group with high fish consumption) could be of great value in the further assessment of this hypothesis in the SAMINOR data.

The results also suggest that in further epidemiological research on the effect of diet in childhood on diseases later in adulthood, it might be superfluous to treat Sámi ethnicity as a covariate with three different levels. It seems that the Sámi III and Sámi II categories could be merged without loss of information. However, merging all Sámi groups may attenuate possible relationships. According to Fig. 2, it seems more prudent to differentiate between ethnicity in the inland areas compared with the coast.

Sámi ethnicity could have been underestimated in our material due to a historical stigma associated with Sámi origin. The fact that only $0.2 \%$ had missing data on the ethnicity variable could indicate a positive attitude towards reporting one's ethnicity. However, we have no information on the tendency to underreport Sámi origin.

The questionnaire was not designed to cover total diet in childhood, but rather to gather information on use of selected foods relevant for the SAMINOR area, and to study the defined dietary clusters' relationship with ethnicity. Our study has shown that data gathered through the limited questionnaire could be used to group the study sample into different dietary clusters, which we believe will be useful for further research on relationships between diet in childhood and health in the Sámi core areas in Norway.

\section{Acknowledgements}

Sources of funding: The SAMINOR study was funded by The Norwegian Ministry of Health.

Conflict of interest declaration: The authors declare that they have no conflicts of interest.

Authorship responsibilities: M.B. wrote the manuscript. C.L.P. developed the food-frequency questionnaire and contributed to the writing of the paper. M.M. conducted the statistical analysis and contributed to the writing of the manuscript. E.L. was the principal investigator.

Acknowledgments: The authors would like to thank Anne Kirsten Anti and Ragnhild Vassvik Kalstad, project workers at the Centre for Sámi Health Research, and the cardiovascular screening team from the Norwegian Institute of Public Health.

\section{References}

1 Brox J, Bjornstad E, Olaussen K. Hemoglobin, iron, nutrition and lifestyle among adolescents in a coastal and an inland community in northern Norway. International Journal of Circumpolar Health 2003; 62: 130-41.

2 Bøe E, Sørlie AA. Kostholdsundersøkelse og helkroppsmålinger på reindriftssamer $i$ Kautokeino 1989 og 1990 [Dietary Assessments and Whole Body Measurements in Reindeer Herding Sámis in Kautokeino 1989 and 1990]. SIS Rapport 1991:10. Oslo: Statens institutt for strålehygiene, 1991.

3 Nilsen H, Utsi E, Bonaa KH. Dietary and nutrient intake of a Sami population living in traditional reindeer herding areas in north Norway: comparisons with a group of Norwegians. International Journal of Circumpolar Health 1999; 58: $120-33$. 
4 Ringstad J, Aaseth J, Johnsen K, Utsi E, Thomassen Y. High serum selenium concentrations in reindeer breeding Lappish men. Arctic Medical Research 1991; 50: 103-6.

5 Kuhnlein HV. Benefits and risks of traditional food for Indigenous Peoples: focus on dietary intakes of Arctic men. Canadian Journal of Biochemistry and Physiology 1995; 73: 765-71

6 Blanchet C, Dewailly E, Ayotte P, Bruneau S, Receveur O, Holub BJ. Contribution of selected traditional and market foods to the diet of Nunavik Inuit women. Journal of the Canadian Dietetic Association 2000; 61: 50-9.

7 Receveur O, Boulay M, Kuhnlein HV. Decreasing traditional food use affects diet quality for adult Dene/Metis in 16 communities of the Canadian Northwest Territories. Journal of Nutrition 1997; 127: 2179-86.

8 Specker BL. Do North American women need supplemental vitamin D during pregnancy or lactation? American Journal of Clinical Nutrition 1994; 59: 484S-90S.

9 Kuhnlein HV. Dietary fat in traditional and contemporary northern indigenous food systems. Arctic Medical Research 1994; 53: 285-8.

10 Haldorsen T, Tynes T. Cancer in the Sami population of North Norway, 1970-1997. European Journal of Cancer Prevention 2005; 14: 63-8.

11 Soininen L, Jarvinen S, Pukkala E. Cancer incidence among Sami in northern Finland, 1979-1998. International Journal of Cancer 2002; 100: 342-6.

12 Michels KB, Rosner BA, Chumlea WC, Colditz GA, Willett WC. Preschool diet and adult risk of breast cancer. International Journal of Cancer 2006; 118: 749-54.

13 Bække U, Laeskogen BM, Øgrim ME. Kostholdsundersøkelser $i$ Kåfjord [Dietary Assessments in Kåfjord]. Melding nr. 12. Oslo: Forskningsresultater fra Landsforeningen for Kosthold og Helse, 1968.

14 Solvang A, Øgrim ME. Kostholdsundersøkelser i Kautokeino og Karasjok [Dietary Assessments in Kautokeino and Karasjok]. Melding nr. 11. Oslo: Forskningsresultater fra Landsforeningen for Kosthold og Helse, 1967.

15 Øgrim ME. Kostholdsundersøkelser ved skoleinternater $i$ Finnmark [Dietary Assessments at Boarding Schools in Finnmark]. Melding nr. 10. Oslo: Forskningsresultater fra Landsforeningen for Kosthold og Helse, 1966.
16 Lund E, Melhus M, Hansen K, Nystad T, Borderstad A-R, Selmer R, et al. Population based study of health and social conditions in areas with both Sami and Norwegian inhabitants - the SAMINOR study. International Journal of Circumpolar Health 2007; 66: 113-28.

17 Aubert V. Den samiske befolkning $i$ Nord-Norge [The Lappish Population in Northern Norway]. Artikler fra Statistisk Sentralbyrå nr. 107 [online], 1978. Available at http://www.ssb.no/histstat/art_107.pdf. Accessed May 2007.

18 Kloster J. The distribution and frequency of rickets in one of the fishery districts of Finnmark and relation of diet to the disorder. Acta Paediatrica 1931; 12: Supplementum III.

19 Larsen A. Sjøsamenes mat og matstell. Om sjøsamene [Sea Sámis' Diet and Cooking. About the Sea Sámis]. Troms $\varnothing$ museums årshefter. Humanistisk avd. nr. 13, 1950: 15-19.

20 Solvang A, Øgrim ME. Kostholdsundersøkelser $i$ Gamvik berred [Dietary Assessments in Gamvik Municipality]. Melding nr. 4. Oslo: Forskningsresultater fra Landsforeningen for Kosthold og Helse, 1963.

21 Everitt BS, Leese M, Landau S. Cluster Analysis. London: Arnold, 2004.

22 Willett WC. Nutritional Epidemiology. New York: Oxford University Press, 1998.

23 Frazier AL, Willett WC, Colditz GA. Reproducibility of recall of adolescent diet: Nurses' Health Study (United States). Cancer Causes \& Control 1995; 6: 499-506.

24 Dwyer JT, Gardner J, Halvorsen K, Krall EA, Cohen A, Valadian I. Memory of food intake in the distant past. American Journal of Epidemiology 1989; 130: 1033-46.

25 Maruti SS, Feskanich D, Colditz GA, Frazier AL, Sampson LA, Michels KB, et al. Adult recall of adolescent diet: reproducibility and comparison with maternal reporting. American Journal of Epidemiology 2005; 161: 89-97.

26 Vestertana og Boftsa skoler/Deanodat. Sjøsamiske mattradisjoner fra vestre Tana/Mearrasámid borramušvieut oarjiit Deanus [Sea Sámi Food Tradition from Western Tana]. Tana: Vestertana og Boftsa skoler, 1994.

27 Norat T, Bingham S, Ferrari P, Slimani N, Jenab M, Mazuir M, et al. Meat, fish, and colorectal cancer risk: the European Prospective Investigation into Cancer and Nutrition. Journal of National Cancer Institute 2005; 97: 906-16. 